\title{
La epopeya burlada: del Libro de buen amor a Juan Goytisolo
}

José María Balcells

Universidad de León, 2016, 210 págs.

La epopeya burlada recoge el fruto de más 30 años de trabajo de investigación dedicados al género de la epopeya burlesca a lo largo de nuestra tradición literaria, campo en el que el autor es destacado especialista desde que en $1983 \mathrm{pu}-$ blicara su edición de La Moschea, de José de Villaviciosa, en la mítica colección "El toro de barro".

El autor organiza el conjunto de sus estudios siguiendo un orden cronológico, y así arranca, como indica el título, con el episodio "De la pelea que ovo Don Carnal con la Quaresma" del Libro de buen amor, donde el interés se centra en la adscripción genérica del fragmento, con la conclusión de que no puede pertenecer al género del debate, como se ha pensado a veces, y tampoco tiene influencia de la Batracomiomaquia, que Juan Ruiz no podía conocer. Balcells lo cree perteneciente al "subgénero de la epopeya alegórica"; en concreto se trataría de un fablel conformado como batalla alegórica. Al tratarse de una parodia de la épica de cle- recía con alguna influencia de los cantares de gesta, no formaría todavía parte de la gran línea de épica burlesca que depende de la inversión de la epopeya clásica. De manera tangencial, pero pertinente, Balcells demuestra que la fuente de Juan Ruiz no fue el fableil francés "Bataille de Caresme et de Charnage".

El problema de adscripción o no al género de la épica burlesca se plantea también para la Batalla campal que los perros y los lobos ovieron, de Alonso de Palencia, que para el crítico tiene una conexión evidente con la Batracomiomaquia; sin embargo, al poner de relieve las diferencias con la obra del pseudoHomero y catalogarla como una parodia política más que literaria, Balcells llega a la conclusión de que tampoco se puede considerar en sentido estricto una epopeya y, desde luego, no influyó en la épica burlesca posterior.

Tras estos antecedentes medievales llegamos a la época de esplendor del género, el Siglo de Oro, 
cuando se conforma tal y como lo conocemos. Comienza Balcells por establecer una serie de distinciones terminológicas que tendrán implicaciones metodológicas a la hora de definir el género y establecer su corpus. Aunque la Batracomiomaquia constituye el paradigma del género y se ha considerado que su imitación constituye una marca de adscripción genérica, sin embargo solo da cuenta de uno de los subgéneros: la zooépica o zoomaquia, pues no todas las epopeyas burlescas siguen el modelo burlesco griego, ni todas las obras que se dicen sus herederas se pueden consdierar adscritas al género.

Los tratadistas de la época, entre ellos el Pinciano y Martínez de Miota en los preliminares de $L a$ Moschea, suelen confundir la teoría del género con la de los niveles de estilo y meten en el mismo saco la genuina épica burlesca y los conocidos como encomia paradoxica, o alabanza de realidades insignificantes y bajas, modalidad que está emparentada con los capitoli de la tradición italiana. De origen italiano es también uno de los componentes que pasa a participar de la conformación del género: los romanzi, objeto de burla por parte de nuestros autores, y principalmente de Lope de Vega, que aglutina la Batracomiomaquia con Ariosto. A esto habría que sumarle la aparición de la fábula mitológica burlesca, lindando también con el género, pero fuera de él.

Desentrañar todo este entramado terminológico, genérico y de influencias es una de las aportaciones importantes del trabajo de Balcells, que le permite, por ejemplo, demostrar que La carajicomedia, a la que se dedica un capítulo entero, aunque puede considerarse teóricamente epopeya burlesca, historiográficamente no pertenece a este género, al no ceñirse al modelo de la Batracomiomaquia. Tampoco se adscribirían la Asneida de Cosme de Aldana y la Asinaria de Rodrigo Fernández de Ribera. Sí lo haría, en cambio, el Viaje del Parnaso, de Cervantes, que antes nunca se había estudiado bajo tal óptica.

Estos deslindes permiten al autor establecer con claridad el corpus del género - con sus diversos subgéneros - en el Siglo de Oro, tomando el modelo de la Batracomiomaquia como núcleo en tanto que marca la línea de la tradición. Con este paradigma se miden la "Guerra de los ratones y los gatos", incluida en el Carlo Famoso, de Luis Zapata de Chaves, la Muracinda de Juan de la Cueva, y sobre todo la Gatomaquia, de Lope de 
Vega, como paradigma hispano del género, en especial por su afinidad con el pseudoHomero en la onomástica. Balcells destaca la obra de Lope de Vega, a la que dedica un capítulo, por su originalidad al haber sabido fundir dos tradiciones: la parodia épica animalística en la línea de la Batracomiomaquia y la de la épica caballeresca italiana, siendo la única de su época que realiza tan innovadora fusión. Como innovadoras ve también Balcells las implicaciones autobiográficas del texto y, sobre todo, la elección de la silva como marco métrico. Lope opta así, con esta ruptura, por un módulo nuevo que permite "ligereza narrativa" así como "gran ductilidad para la estructuración y desarrollo de subtemas y de digresiones variadas" (p. 139).

Igualmente en capítulo aparte, reivindica el autor la centralidad canónica de La Moschea de José de Villaviciosa, a la que no se ha atendido en los estudios literarios con la misma amplitud e intensidad que a la obra de Lope, sobre la que destaca por su mayor ambición y calidad literaria y por hacer un uso más amplio y más original de los pasajes mitológicos, por medio de la amplificatio sistemática de sus fuentes.

Como colofón de la épica bur- lesca en el Siglo de Oro se dedica un capítulo a la curiosa obra $G a$ tomàquia valenciana, de Bartomeu Tormo, secuela de la de Lope, pero de carácter misógino con respecto a su modelo, y de ámbito más limitado, debido a su lectura en clave de personajes, lugares y sucesos locales.

El siglo XVIII, aunque mucho menos estudiado en este aspecto, supone la continuidad del género, que seguiría viviendo momentos de gran vitalidad y productividad. Balcells nos ofrece una completa cronología y corpus de la producción de la época, en la que entraría El Cicerón del padre Isla, aunque sea traducción de una obra italiana; y señala las tendencias principales del desarrollo de la épica burlesca en el siglo ilustrado: con respecto a las modalidades heredadas del siglo XVII, se prolonga la parodia animal, se abandona la ariostesca y se ańaden las influencias francesas, con el modelo de Le lutrin de Boileau, e inglesas, con los poemas burlescos de Pope. Ello supone una renovación temática, a la vez que se produce una renovación métrica con el abandono de la octava real como vehículo exclusivo de expresión, con el antecedente de Lope de Vega.

Es precisamente esa renovación 
temática y formal uno de los factores a los que el autor achaca el declive del género hacia final de siglo, en tanto que supuso la reducción considerable del carácter paródico que singularizaba al género. $\mathrm{El}$ abuso y la preminencia del verso corto frente al heroico contribuiría a desdibujar la parodia del lenguaje elevado, y por otra parte la dimensión lúdica inherente a la parodia perdería terreno con respecto a la lección moral y el espíritu reformista. Tampoco se produjo en el siglo XVIII, sigue argumentando Balcells, ninguna obra excepcional en este terreno, a lo que habría que añadir la aparición de nuevas ideas estéticas a principios del XIX que no fomentan la composición de este tipo de textos.

El paseo por la Ilustración se completa con la atención a poemas tan poco conocidos como $E l$ Morión de Juan Pablo Forner y la Huerteida de Leandro Fernández de Moratín, textos ambos muy fragmentarios y escritos al calor de la polémica por la publicación del Theatro Hespañol de Vicente García de la Huerta. El problema que plantea El Imperio de la estupidez de Alberto Lista es de otro tenor, al tratarse de una traducción libre del poema de Pope. Sobra las dudas que arroja su originalidad, Balcells se inclina a considerar que la transformación y adaptación del texto inglés al panorama español es tal que se puede considerar obra original de Lista. En cuanto al género y su pertenencia o no a la épica burlesca, el propio Lista reconoce que no es por completo ni una epopeya ni una sátira, sino un género híbrido, una sátira "en la que los caracteres ridículos se visten a la heroica" (p. 184).

Las derivaciones de la épica burlesca en los siglos XIX y XX y su pervivencia ya en forma intertextual llevan al autor a fijarse en el cuento de Clarín, "La mosca sabia”, que aparece catalogado como cuento fantástico, y que demuestra por parte de su autor un conocimiento notable de la Batracomiomaquia, La Moschea y La Gatomaquia, señalando a Clarín como gustador de las epopeyas burlescas. La Carajicomedia de Juan Goytisolo cierra el ciclo, como parodia de segundo grado, lo que da pie no solo para la comparación con el texto medieval, sino también para un interesante acercamiento a los problemas de la modernidad literaria.

El libro constituye, pues, un completo panorama del género burlesco en nuestra literatura; una demostración de lo complejo de su 
realidad y de la necesidad de nuevos y diversos tratamientos que coloquen a estos textos en el lugar que les corresponde; principalmente en el panorama de nuestro Siglo de Oro, donde siguen sin contar con el espacio que merecen, debido a la pervivencia todavía de los prejuicios con que los observó el siglo XIX, el mismo que vio nacer la historiografía literaria. El libro de Balcells deja claros los límites del género y a la vez su flexibilidad, pues en él caben obras que antes no se habían considerado dentro de este marbete, como El viaje del Parnaso. Ello abre la puerta a posibles futuras adscripciones $y$, sobre todo, a nuevas perspectivas de estudio, al optar el autor, con acierto, por una doble caracterización genérica: una de tipo teórico y otra en términos de tradición literaria.

Nos felicitamos, pues, de contar con el conjunto de estudios más completo y actualizado sobre un género desatendido y que todavía puede deparar dichosas sorpresas filológicas.

Ángel Luis Luján Atienza Universidad de Castilla La Mancha 